\title{
In silico Study, Protein Kinase Inhibition and Antiproliferative Potential of Flavonoids Isolated from Bassia eriophora (Schrad.) Growing in KSA
}

\author{
Arafa Musa ${ }^{1,2}$, Mohammad Mahmoud Al-Sanea ${ }^{3}$, Nasser Hadal Alotaibi ${ }^{4}$, Taghreed Stum Alnusaire ${ }^{5}$, \\ Shaimaa Rashad Ahmed ${ }^{1,6}$, Ehab Mohamed Mostafa ${ }^{1,2, *}$ \\ ${ }^{1}$ Department of Pharmacognosy, College of Pharmacy, Jouf University, Sakaka, Aljouf 72341, SAUDI ARABIA. \\ 2Department of Pharmacognosy, Faculty of Pharmacy, Al-Azhar University, Cairo 11371, EGYPT. \\ ${ }^{3}$ Pharmaceutical Chemistry Department, College of Pharmacy, Jouf University, Sakaka, Aljouf 72341, SAUDI ARABIA. \\ ${ }^{4}$ Department of Clinical Pharmacy, College of Pharmacy, Jouf University, Sakaka, Aljouf 72341, SAUDI ARABIA. \\ ${ }^{5}$ Biology Department, College of Science, Jouf University, Sakaka, Aljouf 72341, SAUDI ARABIA. \\ ${ }^{6}$ Department of Pharmacognosy, Faculty of Pharmacy, Cairo University, Cairo 11562, EGYPT.
}

\begin{abstract}
Introduction: Kinase enzymes play an important role in cellular proliferation, the main target in cancer treatment is to inhibit their functions. Protein kinase inhibitors as flavonoids can be applied for prevention or treatment of cancers through inhibition of cell proliferation. Objectives: To isolate cytotoxic metabolites from $B$. eriophora, evaluate their antiproliferative and protein kinase inhibitory effects, as well as the in silico study for active compounds. Materials and Methods: Preparative HPLC was used for purification of the isolates. NMR, MS and UV spectroscopy were applied for characterization of the pure compounds. Sulphorhodamine-B and radiometric assay methods were employed for determination of the antiproliferative and protein kinase inhibition activities, respectively. The antiproliferative mechanism was predicted by in silico study using Molecular Operating Environment (MOE). Results: Five flavonoids; luteolin, acacetin-7- $O-\beta$-D-glucoside, diosmin, kaempferol-3-O-rutinoside and rutin were isolated and investigated for their antiproliferative and kinase inhibitory effects. Luteolin exhibited strong antiproliferative effect against certain cell lines including MCF-7, HepG2 and HCT-116 with IC ${ }_{50}(33.24 \pm$ $0.83,26.54 \pm 1.02$ and $31.62 \pm 1.32 \mu \mathrm{M}$, respectively), while diosmin and kaempferol3-O-rutinoside showed strong antiproliferative effect against MCF-7 with IC ${ }_{50}(26.56 \pm$ 1.12 and $28.72 \pm 0.98$ ). Luteolin showed highest inhibitory effect against Aurora B and CDK4/CyclinD1 with $\mathrm{IC}_{50} 3.16$ and $4.95 \mathrm{~m} 3.16$ and 4.95 inhibitin slico study for the isolated metabolites against Aurora $B$ and CDK4/CycD1 confirmed their cytotoxic profile. Conclusion: Five flavonoids were firstly isolated from $B$. eriophora. The putative antiproliferative mechanism of luteolin and kaempferol-3-O-rutinoside on Aurora B and CDK4/CycD1 kinases was predictable by in slico study.
\end{abstract}

Key words: Bassia eriophora, Antiproliferation, in silico study, Flavonoids, Protein kinase.

\section{INTRODUCTION}

Discovery of natural anticancer drugs is the main target for researchers and scholars since the last few decades. Protein kinase enzymes play an important role in phosphorylation of specific protein substrate, through transfer of the terminal phosphate moiety of adenosine triphosphate (ATP) molecule. ${ }^{1,2}$ The genome of human body contains approximately 538 different protein kinases, which are categorized into three different families based on their selectivity for protein substrates. ${ }^{3,4}$ To achieve phosphorylation process, a free hydroxyl moiety is required in the protein substrate, which is freely available in serine, threonine and tyrosine residues. Accordingly, serine/threonine kinase family can identify and attach a phosphate group to a serine or threonine residues, while
Submission Date: 20-07-2020; Revision Date: 22-12-2020; Accepted Date: 01-03-2021

DOI: 10.5530/ijper.55.2.86 Correspondence:

Dr. Ehab M Mostafa 1Department of

Pharmacognosy, College of Pharmacy, Jouf University, Sakaka, Aljouf 72341

SAUDI ARABIA.

2Department of

Pharmacognosy, Faculty of Pharmacy, Al-Azhar University, Cairo-11371 EGYPT.

Phone no: +966-54-0470403 Email id: emmoustafa@ ju.edu.sa

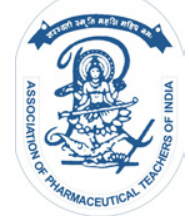

www.ijper.org 
the tyrosine and histidine specific protein kinases can phosphorylate a protein at a tyrosine or histidine moieties. Serine/threonine type including Aurora and CDKs kinases contribute in cell division through regulation of the mitotic progression signaling, deregulation of protein kinases is implicated in tumorigenesis. ${ }^{5}$ Accordingly, one the major drug targeting in cancer treatment depends completely on kinase inhibition. The development and isolation of natural kinase inhibitors has been predicted to be a major object of pharmaceutical growth with more than 135 kinase inhibitors described to be in either Phase I or Phase II clinical trials, most of these drugs being tested for their potential as anticancer agents. Flavonoids are considered one of the best known naturally occurring anticancer drugs which are ubiquitous in most of plant species. Owing to their high potential as radical scavengers, flavonoids are employed as strong antioxidants, chemopreventive and chemotherapeutic drugs in various types of tumor. ${ }^{6,7}$ The preliminary phytochemical and biological investigations of Bassia eriophora (Chenopodiaceae) resulted in detection of flavonoids as the major content with few data about its biological activities. ${ }^{8-10}$ The goal of this research is to focus on isolation and exploration of the anticancer flavonoids of $B$. eriophora growing in the north of Kingdom Saudi Arabia. The antiproliferative and protein kinases inhibitory effects as well as the in silico study were conducted on the pure isolates.

\section{MATERIALS AND METHODS}

\section{General experimental procedures}

The spectral measures (MS, UV, NMR) were assessed and recorded by using the standard techniques and applying official apparatus. The NMR $\left({ }^{1} \mathrm{H}\right.$-and $\left.{ }^{13} \mathrm{C}\right)$ were determined from Bruker ARX-500 spectrometer, operating at $500 \mathrm{MHz}$ for $1 \mathrm{H}$ ) and $125 \mathrm{MHz}$ for ${ }^{13} \mathrm{C}$ in DMSO-d6 or CD3OD solvents. TMS was applied as reference standard, coupling constants (J-value/ $\mathrm{Hz})$ and chemical shifts $(\delta / \mathrm{ppm})$ were recorded by the standard Bruker software (Bruker AG, Switzerland). Recording of Mass spectra was achieved by electrospray ionization (ESI-MS), Thermo Finnigan LCQ DECA mass spectrometer (Waldbronn, Germany) supported by Agilent 1100 HPLC system (LMU, Munich, Germany) and equipped with a photodiode array detector. Preparative HPLC was performed on Agilent 1290 infinity II binary pump with prep- $\mathrm{C}_{18}(21.2 \times 50 \mathrm{~mm})$ column with flow rate $20 \mathrm{~mL} / \mathrm{min}$, connected to Agilent 1290 infinity II prep column chamber, Agilent 1260 infinity II prepauto-sampler and Agilent 1260 infinity II prep fraction collector with tray holding 40 tubes $30 \mathrm{x}$
$100 \mathrm{~mm} 50 \mathrm{ml}$ (Agilent, Victoria, USA). Detection was achieved with 1260 infinity II diode array detector WR, the chromatograms were noted at different wavelengths (235, 254, 280 and $340 \mathrm{~nm}$ ) (Agilent, Victoria, USA). Vacuum liquid chromatography column (VLC) was carried out by using normal Silica Gel 60, 0.04-0.063 mm mesh size (Merck, Germany). Sephadex LH-20 (Merck, Germany) was employed as stationary phases for open column chromatography to improve purification steps. The TLC chromatogram was visualized by UV-lamp (254 and $365 \mathrm{~nm}$ ), VL-6.LC, 24W, France and by spraying with $\mathrm{AlCl}_{3}$ reagent specific for flavonoids.

\section{Plant material}

B. eriophora (Schrad.) Asch. was collected in April 2019, around the campus of Jouf university, Sakaka, Aljouf, KSA. Identity of the plant was confirmed by Mr. Al-Hassan Hamdan, Camel Research Center, Sakaka, Aljouf, KSA. A voucher specimen (58-CPJU) has been archived in Pharmacy College, Jouf University.

\section{Extraction and Isolation}

The standard extraction method was applied by soaking the plant powder in the selective solvent. ${ }^{11}$ The whole plant was air dried $(1 \mathrm{~kg})$, powdered and macerated in $70 \% \mathrm{EtOH}$ for three times till exhaustive extraction $(8 \mathrm{~L} \times 3)$. The resulting total extract $(42 \mathrm{~g})$ was mixed with dist. $\mathrm{H}_{2} \mathrm{O}$, defatted with $n$-hexane $(21 \mathrm{~g})$, followed by extraction with ethyl acetate to yield $8 \mathrm{~g}$. The EtOAc fraction was divided on VLC silica gel column chromatography, the eluent was composed of methylene chloride and methanol mixture in gradient manner, monitoring of the eluates was achieved by the pre-coated TLC plates. ${ }^{12-14}$ Visualization was achieved by $\mathrm{AlCl}_{3}$ spray reagent, after being visualized under UV-lamp (254, 365 $\mathrm{nm})$. According to the TLC patterns, six fractions were collected (fr. I-VI). Fr. II was applied on normal silica gel column and eluted with $\mathrm{MeOH}$ in DCM, depending on the TLC plates monitoring, compound 1(22 mg) was obtained with $2 \% \mathrm{MeOH}$ in DCM. By applying the same isolation technique, fr. III was chromatographed to on normal $\mathrm{Si}$ gel column and eluted by $\mathrm{MeOH}$ in DCM till detection of the target compound $2(25 \mathrm{mh})$ at $8 \% \mathrm{MeOH}$ in DCM. Where fr. V showed interesting spots on TLC, it was chromatographed by as fr. II and III with the same solvent mixture to produce 5 different sub fractions (fr. $\mathrm{V}_{1-5}$ ), fr. $\mathrm{V}_{1,2,5}$ were selected for further chromatographic separation, they were separately chromatographed on normal Si-gel column. Upon continuous elution with $\mathrm{MeOH} / \mathrm{DCM}$ mixture, Fr. $\mathrm{V}_{1}$ afforded compound $3(18 \mathrm{mg})$ at $11 \% \mathrm{MeOH}$ in DCM, while fr. $\mathrm{V}_{2}$ afforded compound $4(25 \mathrm{mg})$ at $13 \% \mathrm{MeOH}$ 
in DCM. Additionally, fr. $\mathrm{V}_{5}$ yielded compound 5 (17 mg) at $14 \% \mathrm{MeOH}$ in DCM. All isolates were purified by elution with $\mathrm{MeOH}$ on Sephadex LH-20, final purification was achieved by injection of the individual isolates on Agilent infinity II prep HPLC system with one-hour program; $10 \%$ methanol (in nano pure water) for $5 \mathrm{~min}$, 11 to $85 \%$ methanol for $45 \mathrm{~min}$, isocratic 100\% methanol for $5 \mathrm{~min}$ and finally gradient to the initial condition for $5 \mathrm{~min}$ at flow rate of $20 \mathrm{~mL} / \mathrm{min}$. The retention time for elution of each individual was; (compound 1; $\mathrm{R}_{\mathrm{t}}=21.5$, compound 2; $\mathrm{R}_{\mathrm{t}}=20.2$, compound 3; $\mathrm{R}_{\mathrm{t}}=19.6$, compound $4 ; R_{t}=19.1$ and compound $\left.5 ; R_{t}=18.5\right)$. More details are found in the supporting material.

\section{Antiproliferative assay}

The pure isolates have been evaluated for their cytotoxicity against MCF-7, HepG2 and HCT-116, cell lines. The sulphorhodamine-B (SRB) assay method was conducted in triplicate as reported by Skehan et al. ${ }^{8}$ results were expressed relative to the untreated control cells. DMSO was applied as negative control while doxorubicin as positive standard. More details are found in the supporting material.

\section{Kinase inhibitory assay}

Aurora and CDKs are belonging to serine/threonine protein kinase type that control and regulate the mitotic cell progression; their deregulation is implicated in tumorigenesis. Therapeutic inhibition of these kinases brings great promise as probable anticancer regime due to their importance in the signaling complex of cellular division. A radiometric protein kinase assay was employed to detect the inhibitory effect of the isolated flavonoids on the selected kinases. The procedure depends on incorporation of the radioactive isotope ${ }^{33} \mathrm{P}$ with ATP, which can be determined by using a microplate scintillation counter (Microbeta, Wallac, Finland) as previously described. ${ }^{15}$ Estimation of the $\mathrm{IC}_{50}$ values were conducted in triplicate and calculated by detecting ${ }^{33} \mathrm{P}$ bound to the substrate, if the amount of radioactive ${ }^{33} \mathrm{P}$ bound to substrate decreases, the activity of the tested compounds increases.

\section{Docking study}

The crystallographic structures of $\mathrm{CDK} 4 / \mathrm{CycD} 1$ and Aurora B were obtained from Protein Data Bank [PDB ID: 2 W96 with resolution $2.3 \AA$ and $4 \mathrm{C} 2 \mathrm{~V}$ with resolution $1.49 \AA$, respectively]. MOE, version 2016.08 (Molecular Operating Environment) was applied for analysis of docking study. ${ }^{16-19}$ Estimation of the scoring energy (s), binding approaches and root means of the pure isolates along with the kinases were obtained from docking of the co-crystallised ligands. Preparatory steps were performed before docking including protonation of the structures, energy minimization, running conformational analysis using a systemic search and selecting the least energetic conformer. The interactions of the most active flavonoids with amino-acids and hydrogen bond lengths were detected (Figures 2-5).

\section{RESULTS AND DISCUSSION}

\section{Phytochemical isolation}

The EtOAc fraction was chromatographed on VLC silica gel and Sephadex LH20, followed by prep HPLC to produce five pure isolates. Characterization of the isolated metabolites was achieved by various spectroscopic methods that resulted in (Figure 1).

Luteolin: yellowish-white amorphous powder, two absorptions maxima at $\lambda_{\max }$ (259 and $362 \mathrm{~nm}$ ) were observed in the UV spectrum indicative to flavone nucleus. ESI-MS exhibited peak line at $\mathrm{m} / \mathrm{z}=287$ denoting ( $\mathrm{M}$ $+\mathrm{H})^{+}$for the molecular weight 286 and molecular formula $\mathrm{C}_{15} \mathrm{H}_{10} \mathrm{O}_{6}$. Fragments at $\mathrm{m} / \mathrm{z}=153$ and 135 are characteristic for ring $\mathrm{A}$ and ring $\mathrm{B}$, respectively. The characteristic $\mathrm{ABX}$-spin pattern of $\mathrm{B}$-ring was detected in ${ }^{1} \mathrm{H}-\mathrm{NMR}$ at $\delta 7.35\left(1 \mathrm{H}, \mathrm{d}, J=2.1 \mathrm{~Hz}, \mathrm{H}-2^{\prime}\right), \delta 6.90$ $\left(1 \mathrm{H}, \mathrm{d}, J=8.0 \mathrm{~Hz}, \mathrm{H}-5^{\prime}\right)$ and $\delta .36(1 \mathrm{H}, \mathrm{dd}, J=8.1 / 2.0$ $\left.\mathrm{Hz}, \mathrm{H}-6^{\prime}\right)$, the other two aromatic protons of A-ring appeared at $\delta 6.20(1 \mathrm{H}, \mathrm{d}, J=1.9 \mathrm{~Hz}, \mathrm{H}-6)$ and 6.43 $(1 \mathrm{H}, \mathrm{d}, J=1.9 \mathrm{~Hz}, \mathrm{H}-8)$, the singlet peak at $\delta 6.53$ with one proton integration (H-3), confirmed the flavone type flavonoid. The ${ }^{13} \mathrm{C}$-NMR spectrum revealed the presence of 15 carbon atoms of Luteolin. ${ }^{20}$

Acacetin-7-O- $\beta$-D-glucoside: yellowish-white amorphous powder, it showed two absorptions maxima at $\lambda_{\text {max }}(280$ and $338 \mathrm{~nm})$ in the UV spectrum, together with the chemical shift at $\delta 6.80(1 \mathrm{H}, \mathrm{s}, \mathrm{H}-3)$ in ${ }^{1} \mathrm{H}$ NMR and at $\delta 103.51$ (C-3) in ${ }^{13} \mathrm{C}-\mathrm{NMR}$ spectra, indicating the flavone type flavonoid. ESI-MS exhibited peak line at $\mathrm{m} / \mathrm{z}=447$ denoting $(\mathrm{M}+\mathrm{H})^{+}$for the molecular weight 446 and molecular formula $\mathrm{C}_{22} \mathrm{H}_{22} \mathrm{O}_{10}$. The characteristic $\mathrm{AA}{ }^{\mathrm{B} B}{ }^{`}$ spin system of $\mathrm{B}$-ring was detected in ${ }^{1} \mathrm{H}-\mathrm{NMR}$ at $\delta 7.58\left(2 \mathrm{H}, \mathrm{d}, J=8.6 \mathrm{~Hz}, \mathrm{H}-3,5^{\prime}\right)$ and $\delta 7.68(2 \mathrm{H}, \mathrm{d}$, $\left.J=8.6 \mathrm{~Hz}, \mathrm{H}-2{ }^{\prime}, 6^{\circ}\right), \delta 6.53(1 \mathrm{H}, \mathrm{d}, J=2.5 \mathrm{~Hz}, \mathrm{H}-6)$ and $\delta$ $6.75(1 \mathrm{H}, \mathrm{d}, J=2.5 \mathrm{~Hz}, \mathrm{H}-8)$. Additionally, at $\delta 3.90$ and $\delta 55.17$ are indicative to $\mathrm{O}-\mathrm{CH}_{3}$ group. The ${ }^{1} \mathrm{H}-\mathrm{NMR}$ resonances at $\delta 5.42-3.34 \mathrm{ppm}$ and six signals in the ${ }^{13} \mathrm{C}-\mathrm{NMR}$ spectrum at $\delta 99.74-63.07$ indicated the presence of one sugar moiety. The other ${ }^{13} \mathrm{C}-\mathrm{NMR}$ signals confirmed acacetin-7-O- $\beta$-D-glucoside structure. ${ }^{20}$

Diosmin: The UV spectrum showed two absorptions maxima at $\lambda_{\max }$ (269 and $372 \mathrm{~nm}$ ), together with the appearance of sharp singlet signal for $\mathrm{H}-3$ proton at $\delta$ $6.80 \mathrm{ppm}$, confirmed the flavone skeleton. The ESI-MS 
exhibited a peak line at $\mathrm{m} / \mathrm{z}=609$ denoting $(\mathrm{M}+\mathrm{H})^{+}$ and $608(\mathrm{M})^{+}$for the molecular weight 608and molecular formula $\mathrm{C}_{28} \mathrm{H}_{32} \mathrm{O}_{15}$. The characteristic $\mathrm{ABX}$ spin system of B-ring was detected in ${ }^{1} \mathrm{H}-\mathrm{NMR}$ at $\delta 7.43(1 \mathrm{H}, \mathrm{d}$, $\left.J=2.1 \mathrm{~Hz}, \mathrm{H}-2^{\prime}\right), \delta 7.10\left(2 \mathrm{H}, \mathrm{d}, J=8.30 \mathrm{~Hz}, \mathrm{H}-5^{\prime}\right)$ and $\delta 7.56\left(1 \mathrm{H}, \mathrm{dd}, J=2.12,8.0 \mathrm{~Hz}, \mathrm{H}-6^{`}\right), \delta 6.46(1 \mathrm{H}, \mathrm{d}$, $J=1.92 \mathrm{~Hz}, \mathrm{H}-6)$ and $\delta 6.75(1 \mathrm{H}, \mathrm{d}, J=1.91 \mathrm{~Hz}, \mathrm{H}-8)$. The $\mathrm{OCH}_{3}$ proton signal appeared at $\delta 3.88$ as sharp singlet in ${ }^{1} \mathrm{H}-\mathrm{NMR}$ and integrated for 3 protons, confirmed by the correspondent peak at $\delta 55.84$ in ${ }^{13} \mathrm{C}-\mathrm{NMR} .{ }^{21}$

Kaempferol-3-O-rutinoside: The UV spectrum showed two absorptions maxima at $\lambda_{\text {max }}(260$ and $356 \mathrm{~nm})$, together with the absence of $\mathrm{H}-3$ proton signal suggested its flavonol type. The ESI-MS exhibited a peak line at $\mathrm{m} /$ $\mathrm{z}=595$ denoting $(\mathrm{M}+\mathrm{H})^{+}$for the molecular weight 594 and molecular formula $\mathrm{C}_{27} \mathrm{H}_{30} \mathrm{O}_{15}$. A peak at $\mathrm{m} / \mathrm{z}=617$ $(\mathrm{M}+\mathrm{Na})^{+}$and $\mathrm{m} / \mathrm{z}=287$ (aglycone $\left.+\mathrm{H}\right)^{+}$were also detected. The characteristic AA'BB' spin system of B-ring was detected in ${ }^{1} \mathrm{H}-\mathrm{NMR}$ at $\delta 6.91(2 \mathrm{H}, \mathrm{d}, J=8.87$ $\left.\mathrm{Hz}, \mathrm{H}-3^{\prime}, 5^{\prime}\right)$ and d H-3 (2H, d, J=7.93 Hz, H-2 $\left.{ }^{\prime} 6^{\circ}\right)$, $\delta 6.21(1 \mathrm{H}, \mathrm{d}, J=2.12 \mathrm{~Hz}, \mathrm{H}-6)$ and $\delta 6.42(1 \mathrm{H}, \mathrm{d}, J=2.15$ $\mathrm{Hz}, \mathrm{H}-8)$. The anomeric proton of glucose and rhamnose moieties resonated at $\delta 5.33\left(1 \mathrm{H}, \mathrm{d}, J=7.41 \mathrm{~Hz}, \mathrm{H}-1^{\prime \prime}\right)$ and $\delta 5.36\left(1 \mathrm{H}, \mathrm{d}, J=2.94 \mathrm{~Hz}, \mathrm{H}-{ }^{\prime}{ }^{\prime \prime}\right)$, respectively. The $\mathrm{CH}_{3}$ signal was clearly observed at $\delta 1.01(1 \mathrm{H}, \mathrm{d}, J=6.21)$. the ${ }^{13} \mathrm{C}$-NMR signals were compatible with the elucidated structure. ${ }^{17}$

Rutin: The UV spectrum showed two absorptions maxima at $\lambda_{\max }$ (256 and $359 \mathrm{~nm}$ ), together with the absence of $\mathrm{H}-3$ proton signal suggested its flavonol type. The ESI-MS exhibited a peak line at $\mathrm{m} / \mathrm{z}=611$ denoting $(\mathrm{M}+$ $\mathrm{H})^{+}$for the molecular weight 610 and molecular formula $\mathrm{C}_{27} \mathrm{H}_{30} \mathrm{O}_{16}$. The characteristic $\mathrm{ABX}$ spin system of B-ring was detected in ${ }^{1} \mathrm{H}-\mathrm{NMR}$ at $\delta 7.53(1 \mathrm{H}, \mathrm{d}, J=2.21 \mathrm{~Hz}$, H-2 $), \delta 6.83\left(2 \mathrm{H}, \mathrm{d}, J=8.2 \mathrm{~Hz}, \mathrm{H}-5^{\circ}\right)$ and $\delta 7.55(1 \mathrm{H}$, dd, $J=2.2,8.19 \mathrm{~Hz}, \mathrm{H}-6), \delta 6.19(1 \mathrm{H}, \mathrm{d}, J=2.1 \mathrm{~Hz}, \mathrm{H}-6)$ and $\delta 6.39(1 \mathrm{H}, \mathrm{d}, J=2.1 \mathrm{~Hz}, \mathrm{H}-8)$. The anomeric proton of glucose and rhamnose moieties resonated at $\delta 5.32$ $\left(1 \mathrm{H}, \mathrm{d}, J=8.2 \mathrm{~Hz}, \mathrm{H}-{ }^{\prime}{ }^{\prime}\right)$ and $\delta 5.07(1 \mathrm{H}, \mathrm{d}, J=1.8$ $\left.\mathrm{Hz}, \mathrm{H}-1^{\prime}{ }^{\prime \prime}\right)$, respectively. The $\mathrm{CH}_{3}$ signal was clearly observed at $\delta 0.91(1 \mathrm{H}, \mathrm{d}, J=7.2)$. the ${ }^{13} \mathrm{C}$-NMR signals were compatible with the predicted structure. ${ }^{22}$

It is well established that polyphenolics particularly flavonoids are characterized by their anticancer potential against various cell lines. Owing to their great radical scavenging activity, flavonoids are regarded as protectors to the livings against radicals and carcinogenic reactive oxygen species. The Antiproliferative activity of the flavonoidal isolates has been estimated against three human cell lines; MCF-7, HepG2 and HCT-116. The $\mathrm{SRB}$ assay was applied as standard method. The $\mathrm{IC}_{50}$ for the tested isolates was expressed in $\mu \mathrm{M}$. The tested

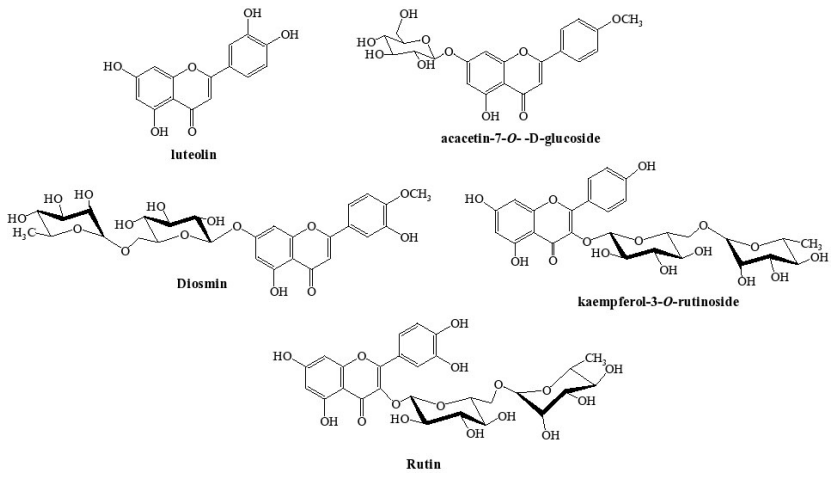

Figure 1: Structures of the isolated flavonoids. Results of Antiproliferative assay

\begin{tabular}{|c|c|c|c|}
\hline \multirow{2}{*}{$\begin{array}{l}\text { Isolated } \\
\text { compounds } \\
(50 \mu \mathrm{L})\end{array}$} & \multicolumn{3}{|c|}{$\mathrm{IC}_{50} \pm \mathrm{SD}(\mu \mathrm{M})^{\mathrm{a}}$} \\
\hline & MCF-7 & HepG2 & НСТ-116 \\
\hline Luteolin & $33.24 \pm 0.83$ & $26.54 \pm 1.02$ & $31.62 \pm 1.32$ \\
\hline $\begin{array}{l}\text { cacetin-7- } O-\beta-D- \\
\text { glucoside }\end{array}$ & $45.18 \pm 0.87$ & $>100$ & $>100$ \\
\hline Diosmin & $25.56 \pm 1.12$ & $84.61 \pm 1.36$ & $>100$ \\
\hline $\begin{array}{l}\text { aempferol-3-O- } \\
\text { rutinoside }\end{array}$ & $28.72 \pm 0.98$ & $53.38 \pm 0.96$ & $>100$ \\
\hline Rutin & $>100$ & $>100$ & $>100$ \\
\hline Doxorubicin & $1.97 \pm 0.46$ & $1.75 \pm 0.29$ & $1.64 \pm 0.43$ \\
\hline
\end{tabular}

${ }^{a}$ Cell proliferation was determined by SRB assay; $I C_{50} \pm S D$ values as $\mu \mathrm{M}$ after $48 \mathrm{~h}$ incubation;

\begin{tabular}{|c|c|c|}
\hline \multicolumn{3}{|c|}{$\begin{array}{c}\text { Table 2: Radiometric assay of the isolated } \\
\text { compounds. }\end{array}$} \\
\hline \multirow{2}{*}{ Compound name } & \multicolumn{2}{|c|}{ Kinase type } \\
\cline { 2 - 3 } & Aurora-B & CDK4/CycD1 \\
\hline Luteolin & 3.16 & 4.95 \\
\hline Acacetin-7-O-B-D-glucoside & 34.12 & 29.56 \\
\hline Diosmin & 26.25 & 31.74 \\
\hline Kaempferol-3-O-rutinoside & 13.54 & 14.76 \\
\hline Rutin & 41.62 & 52.31 \\
\hline
\end{tabular}

$\mathrm{IC}_{50}$ : Inhibitory concentration for $50 \%$

compounds exhibited moderate to strong activity as antiproliferative agents as Table 1.

\section{Protein kinase inhibitory activity}

In order to study the mechanism of action of the isolated flavonoids as anti-proliferative molecules, they were tested for Aurora B and CDK4/CycD1 kinases inhibitory activity. A radiometric method was used to measure the inhibitory activity of these molecules against $\mathrm{CDK} 4 / \mathrm{CycD} 1$ and Aurora B. In vitro kinase assay revealed that compound 1 has significant inhibitory activity on Aurora $\mathrm{B}\left(\mathrm{IC}_{50}=3.16 \mu \mathrm{M}\right)$ more than compounds 


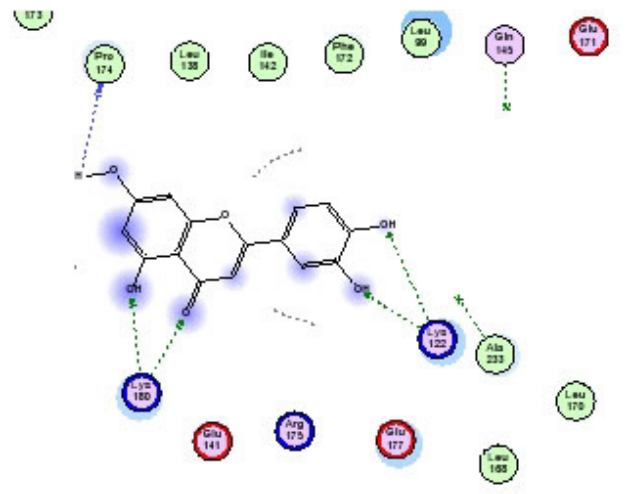

Figure 2a

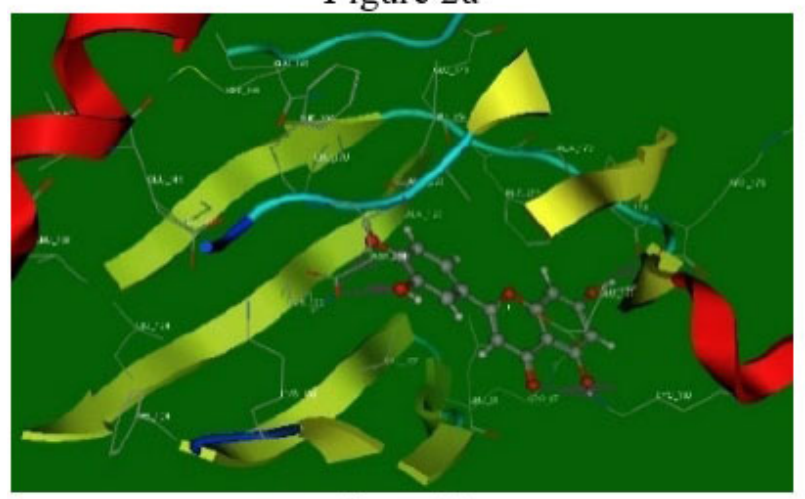

Figure 2b

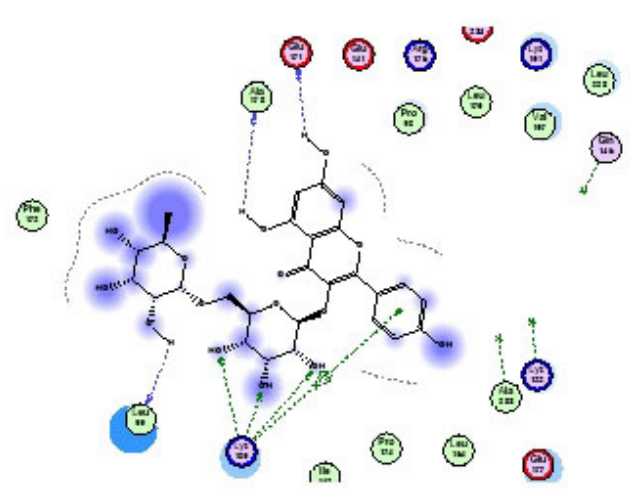

Figure $3 \mathrm{a}$

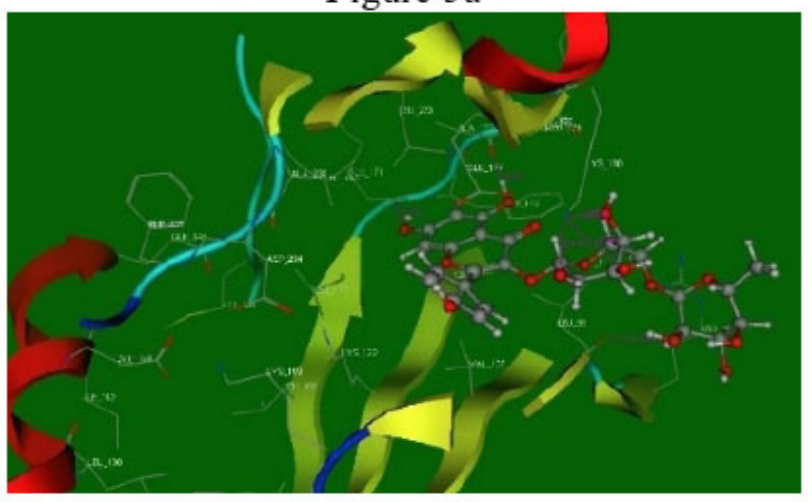

Figure $3 b$

Figure 2-3: (A) 2D; Binding modes and (B) 3D; mapping surface of compounds 1 and 4 with Aurora $B$.

4 and 5 with $\mathrm{IC}_{50}=13.54$ and $41.62 \mu \mathrm{M}$, respectively (Table 2). Furthermore, the inhibitory effect of 1 on $\mathrm{CDK} 4 / \mathrm{CycD} 1\left(\mathrm{IC}_{50}=4.95 \mu \mathrm{M}\right)$ also more active than other compounds, this suggesting that the presence of sugar moiety has an adverse effect on the activity of compounds against protein kinases.

\section{Molecular Docking Study}

The binding poses of the docked compounds 1 and 4 as the most active inhibitory effect on the selected kinase with both Aurora B and CDK4/CycD1, represented promising and valid potential binding modes with the same as for the co-crystalline ligands. ${ }^{23,24}$ The molecular docking study revealed that compound was sitting deeply in the ATP-binding pocket of Aurora B, with binding free energy-21.3469 $\mathrm{kcal} / \mathrm{mol}$ and it participates in hydrogen bonding interactions of $3{ }^{\circ}-\mathrm{OH}$ and $4^{\circ}-\mathrm{OH}$ with Lys122. Additionally, there was hydrogen bonding of 5-OH and 4-carbonyl with Lys180 and 7-OH with Pro174 of ring A of the flavonoid moiety [Figures 2a and $2 \mathrm{~b}]$. The study also displayed the high affinity of compound 4 to Aurora B with score energy $-17.2689 \mathrm{kcal} /$ mol and its binding mode showed interactions with Lys180, Leu99 and Ala173 residues [Figures 3a and 3b]. Furthermore, compounds 1 and 4 displayed the high affinity to CDK4/CycD1 with score energy-19.3755 and $-23.9667 \mathrm{kcal} / \mathrm{mol}$, respectively (Table 3 ) and its binding mode showed hydrogen bonding interactions with Val96 and Ala16 residues for compound 1 (Figures $4 \mathrm{a}$ and 4b) and with Val96, Lys35, Asp97, Thr102 for compound 4 (Figures $5 \mathrm{a}$ and $5 \mathrm{~b}$ ).

\section{CONCLUSION}

Previous study concerning phytochemical and biological investigations of B. eriophora are scarce. As a result of our continuous research on Saudi plants, five phytochemicals have been isolated and characterized by the normal spectroscopic methods. The antiproliferative study of the pure isolates revealed their impact as promising cytotoxic drugs. Diosmin, kaempferol-3-O-rutinoside and luteolin were the most effective metabolites against MCF-7 cell lines, while luteolin exhibited a moderate cytotoxic effect on both HepG2 and HCT-116 cell lines. Moreover, the inhibitory effect of the isolates against Aurora-B and CDK4/CycD1 kinases confirmed their antiproliferative effect against the targeted cell lines. These results reflect the high medicinal value of B. eriophora as cytotoxic drug, which is growing in Aljouf area as 


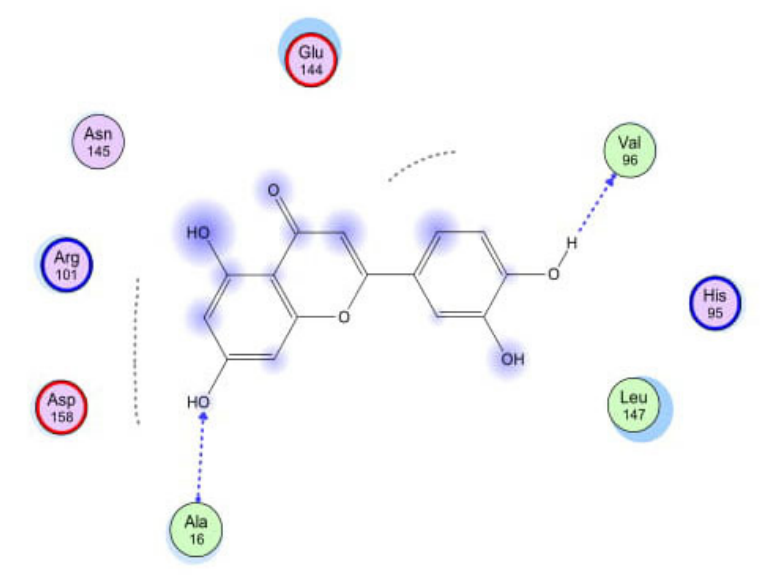

Figure $4 a$

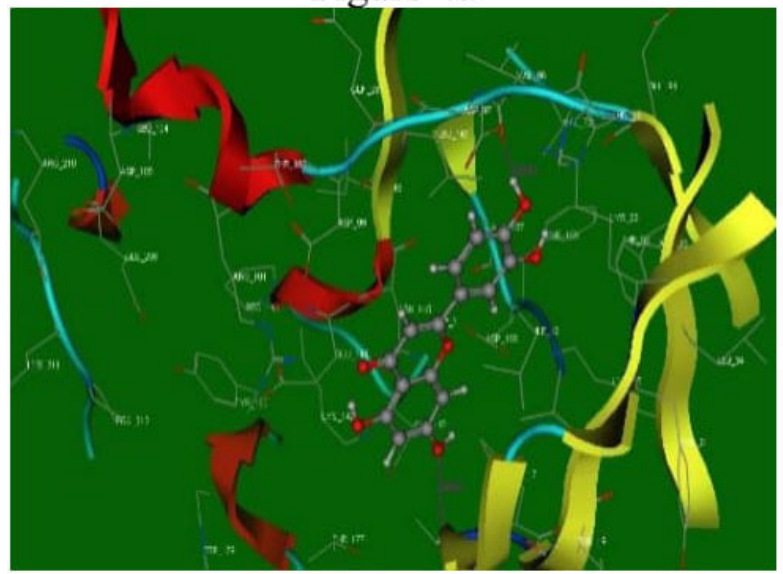

Figure $4 \mathrm{~b}$
(8)

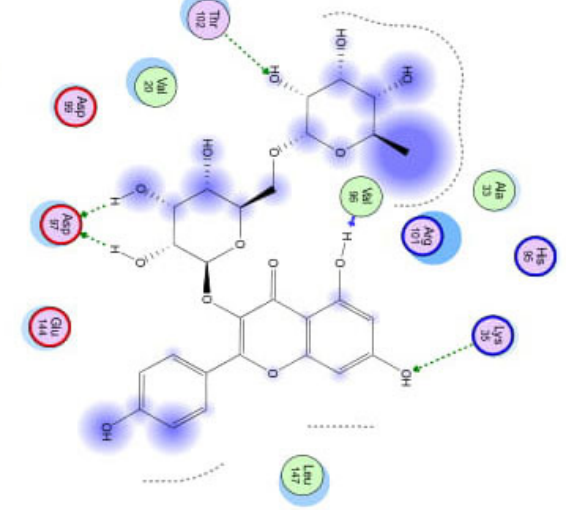

Figure 5a

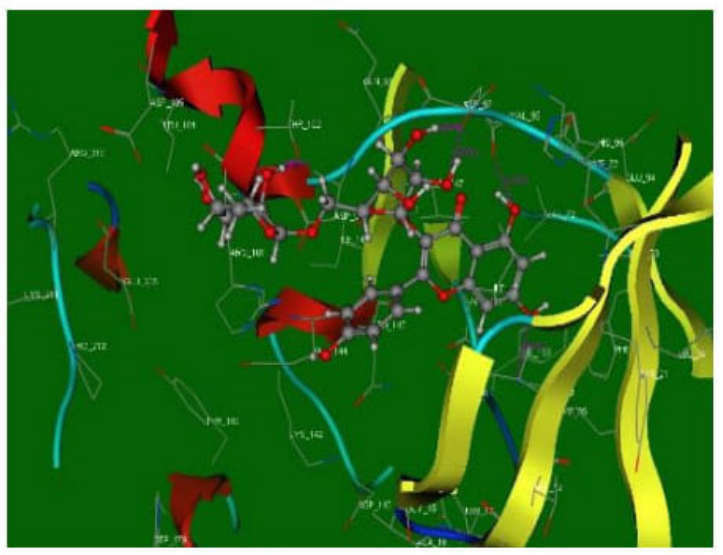

Figure 5b

Figure 4-5: (A) 2D; binding modes and (B) 3D; mapping surface of compounds 1 and4 with CDK4/Cyclin D1.

\begin{tabular}{|c|c|c|c|c|c|}
\hline Receptor & Compound & $\begin{array}{l}\text { Binding free energy } \\
\text { (kcal/mol) }\end{array}$ & $\begin{array}{c}\text { Type of } \\
\text { interaction }\end{array}$ & $\begin{array}{l}\text { Receptor } \\
\text { amino acid } \\
\text { residues }\end{array}$ & $\begin{array}{l}\text { Functional } \\
\text { groups }\end{array}$ \\
\hline \multirow{8}{*}{ Aurora B } & \multirow{4}{*}{ Luteolin } & \multirow{4}{*}{-21.3469} & $\mathrm{H}$ - bond & Lys122 & $\mathrm{OH}$ \\
\hline & & & $\mathrm{H}$ - bond & Lys180 & $\mathrm{OH}$ \\
\hline & & & $\mathrm{H}$ - bond & Lys180 & $\mathrm{C}=\mathrm{O}$ \\
\hline & & & $\mathrm{H}$ - bond & Pro174 & $\mathrm{OH}$ \\
\hline & \multirow{4}{*}{ Kaempferol-3-O-rutinoside } & \multirow{4}{*}{-17.2689} & $\mathrm{H}$ - bond & Lys180 & $\mathrm{OH}$ \\
\hline & & & $\mathrm{H}$ - bond & Leu99 & $\mathrm{OH}$ \\
\hline & & & $\mathrm{H}$ - bond & Ala173 & $\mathrm{OH}$ \\
\hline & & & $\mathrm{H}$ - bond & Glu171 & $\mathrm{OH}$ \\
\hline \multirow{6}{*}{ CDK4/CycD1 } & \multirow{2}{*}{ Luteolin } & \multirow{2}{*}{-19.3755} & $\mathrm{H}$ - bond & Val96 & $\mathrm{OH}$ \\
\hline & & & $\mathrm{H}$ - bond & Ala16 & $\mathrm{OH}$ \\
\hline & \multirow{4}{*}{ Kaempferol-3-O-rutinoside } & \multirow{4}{*}{-23.9667} & $\mathrm{H}$ - bond & Val96 & $\mathrm{OH}$ \\
\hline & & & $\mathrm{H}$ - bond & Lys35 & $\mathrm{OH}$ \\
\hline & & & $\mathrm{H}$ - bond & Asp97 & $\mathrm{OH}$ \\
\hline & & & $\mathrm{H}$ - bond & Thr102 & $\mathrm{OH}$ \\
\hline
\end{tabular}

H-bond; Hydrogen bonding, $\mathrm{OH}_{\text {; }}$ hydroxyl group, $\mathrm{C}=\mathrm{O}$; carbonyl group 
pastoral and grazing plant and can be safely introduced to the traditional medicine.

\section{ACKNOWLEDGEMENT}

The authors appreciate the support of Pharmacognosy Department, College of Pharmacy, Jouf University, KSA.

\section{CONFLICT OF INTEREST}

The authors declare that there is no conflict of interest.

\section{ABBREVIATIONS}

MCF-7: Human breast adenocarcinoma; HepG2: Human hepatocellular carcinoma; HCT-116: Human colorectal carcinoma; B. eriophora: Bassia eriophora; PKs: Protein kinases; SRB: sulphorhodamine-B; MOE: Molecular Operating Environment.

\section{REFERENCES}

1. Vijayalakshmi A, Kumar P, Sakthi PS, Meenaxshi C. In vitro antioxidant and anticancer activity of flavonoid fraction from the aerial parts of Cissus quadrangularis Linn. against human breast carcinoma cell lines. J Chem. 2013

2. Skropeta D, Pastro N, Zivanovic A. Kinase inhibitors from marine sponges. Mar Drugs. 2011;9(10):2131-54.

3. Ogurtsov AY, Mariño-Ramírez L, Johnson GR, Landsman D, Shabalina SA, Spiridonov NA. Expression patterns of protein kinases correlate with gene architecture and evolutionary rates. PLOS One. 2008;3(10):e3599.

4. Bhullar KS, Lagarón NO, McGowan EM, Parmar I, Jha A, Hubbard BP, et al. Kinase-targeted cancer therapies: progress, challenges and future directions. Mol Cancer. 2018;17(1):1-20.

5. Lotha R, Sivasubramanian A. Flavonoids nutraceuticals in prevention and treatment of cancer: A review. Asian J Pharm Clin Res. 2018;11:42-7.

6. Seelinger G, Merfort I, Wölfle U, Schempp CM. Anti-carcinogenic effects of the flavonoid luteolin. Molecules. 2008;13(10):2628-51.

7. Ren W, Qiao Z, Wang H, Zhu L, Zhang L. Flavonoids: promising anticancer agents. Med Res Rev. 2003;23(4):519-34.

8. Musa A, Al-muaikel NS, Abdel-Bakky MS. Phytochemical and pharmacological evaluations of ethanolic extract of Bassia eriophora. Der Pharma Chem. 2016;8(12):169-78.
9. Yusufoglu HS. Pharmacognostic and wound healing studies of the leaves of Bassia eriophora (Family: Chenopodiaceae) on albino rats. Ann Res Rev in Biol. 2015;5(5):400-8.

10. Khalil HE, Aljeshi YM, Saleh FA, Mohamed TS. Assessment of chemical composition and the antimicrobial and antioxidant activities of Bassia eriophora growing in Eastern province of Saudi Arabia. JOCPR. 2017;9(2):210-5.

11. Mahmoud BK, Hamed AN, Samy MN, Mostafa EM, Wanas AS, Radwan MM, et al. Phytochemical composition and antimicrobial properties of Markhamia platycalyx (Baker) Sprague leaf. Trop J Pharm Res. 2019;18(12):2623-31.

12. Musa A. Chemical constituents, antimicrobial and antiinflammatory evaluations of various Extracts of Suaeda vera Forssk. growing in Saudi Arabia. Int J Pharm Res. 2019;11(4):962-7.

13. Abdelgawad MA, Mohamed AM, Musa A, Mostafa EM, Awad HM. Synthesis, chromatographic separation and antimicrobial evolution of new azoquinoline8-ol. J Pharm Sci Res. 2018;10(6):1314-8.

14. Luber M, Musa A, Kadry HA, Bracher F. Isolation of the pyrrolizidine alkaloid intermedine-N-oxide from Cerinthe glabra and ab initio calculation of its $13 \mathrm{C}$ NMR shifts. Z Nat Forsch B. 2012;67(5):411-6.

15. Mostafa EM, Musa A, Abdelgawad MA, Ragab EA. Cytotoxicity, protein kinase inhibitory activity and docking studies of secondary metabolites isolated from Brownea grandiceps Jacq. Pharmacogn Mag. 2019;15(63):438.

16. Ghoneim MM, Musa A, El-Hela AA, Elokely KM. Evaluation and understanding the molecular basis of the antimethicillin-resistant Staphylococcus aureus activity of secondary metabolites isolated from Lamium amplexicaule. Pharmacogn Mag. 2018;14(55):3.

17. Alkhaldi AA, Musa A, Mostafa EM, Amin E, DeKoning HP. Docking studies and antiprotozoal activity of secondary metabolites isolated from Scrophularia syriaca Benth. growing in Saudi Arabia. Rec Nat Prod. 2020;14(1):30.

18. Mostafa EM. Exploration of aurora $B$ and cyclin-dependent kinase 4 inhibitors isolated from Scorzonera tortuosissima Boiss. and their docking studies. Pharmacog Mag. 2020;16(69):258.

19. Mohammed AE-SI, Musa A, Abu-Bakr MS, Abbass HS. Anti-eczematic and molecular modeling of anthraquinones isolated from the seeds of Asphodelus microcarpus salzm. viv. growing in Egypt. Pharmacogn Mag. 2019;15(65):586.

20. El-Desouky SK, Ibrahim LF, Kawashty SA, El-Ansari MA, Kim YS, Chong HS, et al. Phytochemical constituents and biological activities of Origanum syriacum. Z Nat Forsch B. 2009;64(4):447-51.

21. Nieto J, Gutierrez A. $1 \mathrm{H}$ NMR spectra at $360 \mathrm{MHz}$ of diosmin and hesperidin in DMSO solution. Spectrosc Lett. 1986;19(5):427-34.

22. DeOliveira DM, Siqueira EP, Nunes YR, Cota BB. Flavonoids from leaves of Mauritia flexuosa. Rev Bras Farmacogn. 2013;23(4):614-20.

23. Chohan TA, Qayyum A, Rehman K, Tariq M, Akash MSH. An insight into the emerging role of cyclin-dependent kinase inhibitors as potential therapeutic agents for the treatment of advanced cancers. Biomed Pharmacother. 2018;107:1326-41.

24. Zheng $Y$, Zheng $M$, Ling $X$, Liu $Y$, Xue $Y, A n ~ L$, et al. Design, synthesis, quantum chemical studies and biological activity evaluation of pyrazolebenzimidazole derivatives as potent Aurora A/B kinase inhibitors. Bioorg Med Chemistry Lett. 2013;23(12):3523-30. 
PICTORIAL ABSTRACT

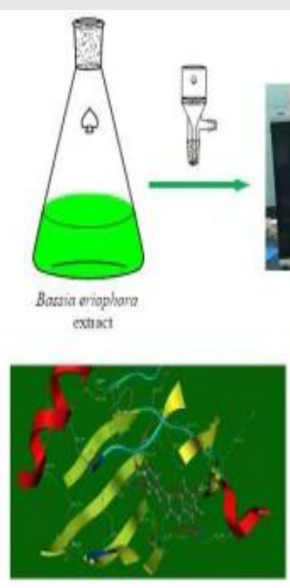

(2) (4) (2)

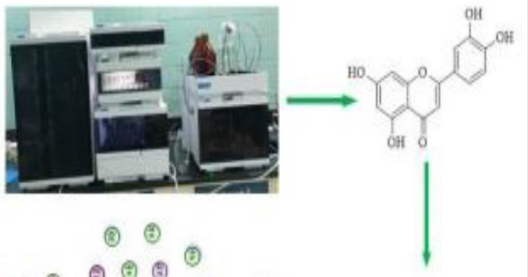

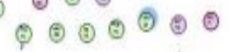

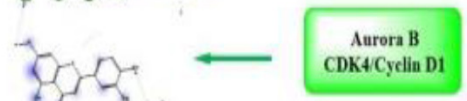

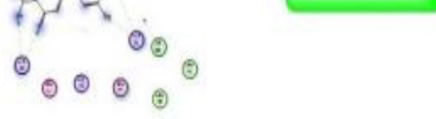

\section{SUMMARY}

Five flavonoids were isolated and identified for the first time from B. eriophora, the cytotoxic activity of the isolated molecules was screened on three different cell lines including MCF-7, HepG2 and HCT-116, Diosmin, kaempferol-3-O-rutinoside and luteolin were the most effective metabolites. In silico study of the highly active molecules on Aurora B and CDK4/CycD1 confirmed its antiproliferative effect.

\section{About Authors}

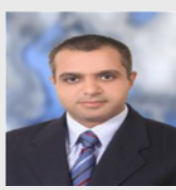

Dr. Ehab M Mostafa Department of Pharmacognosy, College of Pharmacy, Jouf University, Sakaka, Aljouf 72341, Saudi Arabia and Department of Pharmacognosy, Faculty of Pharmacy, Al-Azhar University, Cairo 11371, Egypt.

Cite this article: Musa A, Al-Sanea MM, Alotaibi NH, Alnusaire TS, Ahmed SR, Mostafa EM. In silico Study, Protein Kinase Inhibition and Antiproliferative Potential of Flavonoids Isolated from Bassia eriophora (Schrad.) Growing in KSA. Indian J of Pharmaceutical Education and Research. 2021;55(2):483-90. 